Volume 1, Nomor 1, September 2020, 25-32

BEMAS: JURNAL BERMASYARAKAT

p ISSN 27455866 | e ISSN xxxx xxxx

\title{
LINGKUNGAN EKSTERNAL BISNIS DALAM PERENCANAAN STRATEGIS SISTEM INFORMASI PADA PERUSAHAAN KERUPUK DI KABUPATEN INDRAMAYU
}

\author{
Sumardiono $^{1 *}$ \\ 1* Program Studi Manajemen Informatika, AMIK Purnama Niaga, Indramayu, Indonesia \\ Email: *dyons.2015@gmail.com
}

\author{
INFORMASI ARTIKEL \\ Article History: \\ Submission: 20-08-2020 \\ Revised: $30-08-2020$ \\ Accepted: 16-09-2020 \\ Published: $30-09-2020$ \\ * Korespondensi: \\ Sumardiono \\ dyons2015@gmail.com
}

\begin{abstract}
ABSTRAK
Perkembangan perdagangan modern sangat dipengaruhi dengan kemajuan dan kemudahan dalam sistem informasi. Pelayanan bisnis dan pemasaran sangatlah menunjang dalam pengaksesan dunia digital yang biasa kita kenal dengan e-shop dan e-bisnis. Usaha di zaman milenial tentulah berkembang dalam usaha dari berukuran kecil sampai menengah (IKM) atau industri rumah (home industry). Dengan menjamurnya suatu industri rumah/ IKM, maka masyarakat dapat dikatakan memodernkan zaman, yang mana zaman sebelum mengenal digital hingga mengenal sistem digital. PD. Indrasari merupakan salah satu usaha rumahan atau IKM yang lingkup bisnisnya masih dapat dikatakan konvensional baik secara pemasaran produk ataupun secara pengolahan barang, sehingga melibatkan para tetangga dalam pengolahannya. Strategi bisnis yang masih datar, tanpa adanya layanan bisnis yang menggunakan teknologi dan sistem informasi. Untuk itu, perlunya ada konsep/ gagasan dalam pengembangan usaha yang menggunakan sistem informasi dengan melihat lingkungan eksternal bisnis yang ada di PD. Indrasari. Dengan menggunakan analisis PEST dan analisis Five Porter Forces di dalam metode ward and peppard menghasilkan suatu konsep bisnis terutama eksternal dalam pengembangan dan perencanaan strategi sistem informasi, sehingga persaingan bisnis akan lebih terasa oleh PD. Indrasari.

Kata Kunci: Home Industry, UKM, PEST, dan Five Porter Forces

\section{BUSINESS EXTERNAL ENVIRONMENT IN INFORMATION SYSTEM STRATEGIC PLANNING IN KERUPUK COMPANIES IN} INDRAMAYU DISTRICT

ABSTRACT

The development of modern trade is very much influenced by the progress and convenience of information systems. Business and marketing services are very supportive of accessing the digital world, which we are familiar with as e-shops and e-businesses. Businesses in the millennial era certainly develop in businesses from small to medium size (IKM) or home industry (home industry). With the mushrooming of a home industry / $I K M$, it can be said that people are modernizing the era, which was before knowing digital to knowing the digital system. PD. Indrasari is a homebased business or IKM whose business scope can still be said to be
\end{abstract}


Lingkungan Eksternal Bisnis Dalam Perencanaan Strategis Sistem Informasi Pada Perusahaan

Kerupuk Di Kabupaten Indramayu

conventional, both in terms of product marketing and processing of goods, thus involving neighbors in its processing. A business strategy that is still flat, without any business services that use information technology and systems. For this reason, it is necessary to have a concept/idea in developing a business that uses information systems by looking at the external environment of the business in PD. Indrasari. Using PEST analysis and Five Porter Forces analysis in the ward and Peppard method produces a business concept, especially external in the development and planning of information systems strategy so that business competition will be felt more by $P D$. Indrasari.

Keywords: Home Industry, UKM, PEST, and Five Porter Forces

\section{PENDAHULUAN}

Perdagangan merupakan suatu komoditas yang sangat menguntungkan bagi para pengusaha dan investor [1], sehingga dibutuhkannya suatu rumusan bahkan arah dari suatu perdagangan yang kekinian. Sifat modernisasi selalu diiringi dengan teknologi yang teruji akan keamanan dan dari segi manfaat yang lebih, sehingga memberikan keuntungan bagi beberapa pihak, tidak terkecuali dari sektor perdagangan.

Perdagangan yang melibatkan dengan beberapa kelompok usaha yang biasanya dilakukan oleh orang-orang di lingkungannya sehingga memberikan nilai ekonomis, disebut home industry[2]. Biasanya home industri bermula dari keluarga yang memiliki kreativitas dalam memperoleh nilai ekonomis sehingga memberikan dampak terhadap lingkungan sekitar rumahnya. Tumbuh kembangnya industri rumahan atau bisa disebut dengan nama industri kecil [3] dan menengah (IKM) dari tahun ke tahun, sehingga diharapkan oleh pemerintah dapat tumbuh lebih di tahun 2019 hingga mencapai 5000 IKM. Sebagaimana disampaikan oleh Dirjen IKM Kemenperin [4], “ Menurut informasi tahun 2017, IKM sudah berdiri 1730 yang sudah mengikuti workshop e-Smart IKM. Pada tahun 2018 IKM ditargetkan bertambah menjadi 4000 dan untuk tahun 2019 ditargetkan dapat mencapai 5000 IKM.

Perindustrian di Kabupaten Indramayu yang bergerak dalam industri kecil dan menengah (IKM) masih tergolong kecil dari jumlah pertumbuhannya karena masyarakat Indramayu masih awam dalam menggerakan ekonomi kreatif. Di tahun 1970-an, tepatnya di desa Kenanga Kecamatan Sindang Kabupaten Indramayu awal industri rumahan dengan hasil olahannya berupa kerupuk. Home industri ini dilakukan oleh salah seorang mantan pekerja dari saudagar dari cina, yaitu H. Saein. Yang bermula dari rumah ke rumah, sehingga berkembang menjadi industri yang menengah dengan memperoleh keuntungan lebih dari 500 juta/ tahun. Hanya dalam memasarkan produknya masih bersifat konvensional, tanpa adanya campur tangan teknologi dan sistem informasi. Kurangnya dukungan teknologi dan sistem informasi dalam menggerakan perindustrian dan perdagangan, sehingga kebanyakan peminat dan penikmat tidak mengetahui apakah kerupuk yang bercita rasa udang dan ikan.

Pada tahun 2000-an, IKM Indramayu meningkat khususnya IKM dalam jenis olahan ikan. Di tahun 2015 dibentuklah kumpulan IKM pengusaha kerupuk, yaitu Asosiasi Pengusaha Kerupuk Indramayu (APKI). Salah satu anggota APKI dalam pelaksanaan pengabdian pada masyarakat adalah PD. Indrasari. PD. Indrasari merupakan industri rumahan atau IKM yang lingkup bisnisnya masih dapat dikatakan konvensional baik secara pemasaran produk ataupun secara pengolahan barang, sehingga melibatkan para tetangga dalam pengolahannya. Pengenalan IT/IS kepada mitra perlu dilaksanakan secara masif, sehingga akan memperoleh data sesuai dengan metode yang diinginkan. 
Base on strategic planning of information system (IS) and information technology (IT) which refer to strategy of the business should be customized to the company's business process [5]. Perencanaan strategis adalah suatu proses pemilihan tujuan perusahaan, penentuan kebijakan dan program yang perlu untuk mencapai sasaran tertentu agar kebijakan dan program strategis tersebut terlaksana. Pengertian sistem informasi adalah kumpulan dari komponen-komponen dalam perusahaan atau suatu organisasi yang merupakan hubungan dengan penciptaan aliran informasi [6]. Perencanaan strategis pada SI/TI merupakan suatu proses identifikasi portofolio aplikasi Sistem Informasi SI berbasis komputer yang akan mendukung organisasi dalam pelaksanaan rencana bisnis dan merealisasi tujuan bisnisnya [7]. Ward \& Peppard [8], The strategy defines the organization's requirement or 'demand' for information and system to support the overall strategy of the business. It is firmly grounded in the business, taking into consideration both the competitive impact and alignment requirements of IS/TI.

Berdasarkan latar belakang di atas, bahwa perlunya dukungan teknologi dan sistem informasi salah satunya dengan melihat lingkungan bisnis eksternal dalam suatu perencanaan sistem informasi yang strategis. Oleh karena itu, penulis akan meneliti dengan bertemakan "Lingkungan Eksternal Bisnis dalam Perencanaan Sistem Informasi Strategis pada Perusahaan Kerupuk di Kabupaten Indramayu (Studi Kasus PD. Indrasari)".

1.1 Lingkungan Bisnis Eksternal

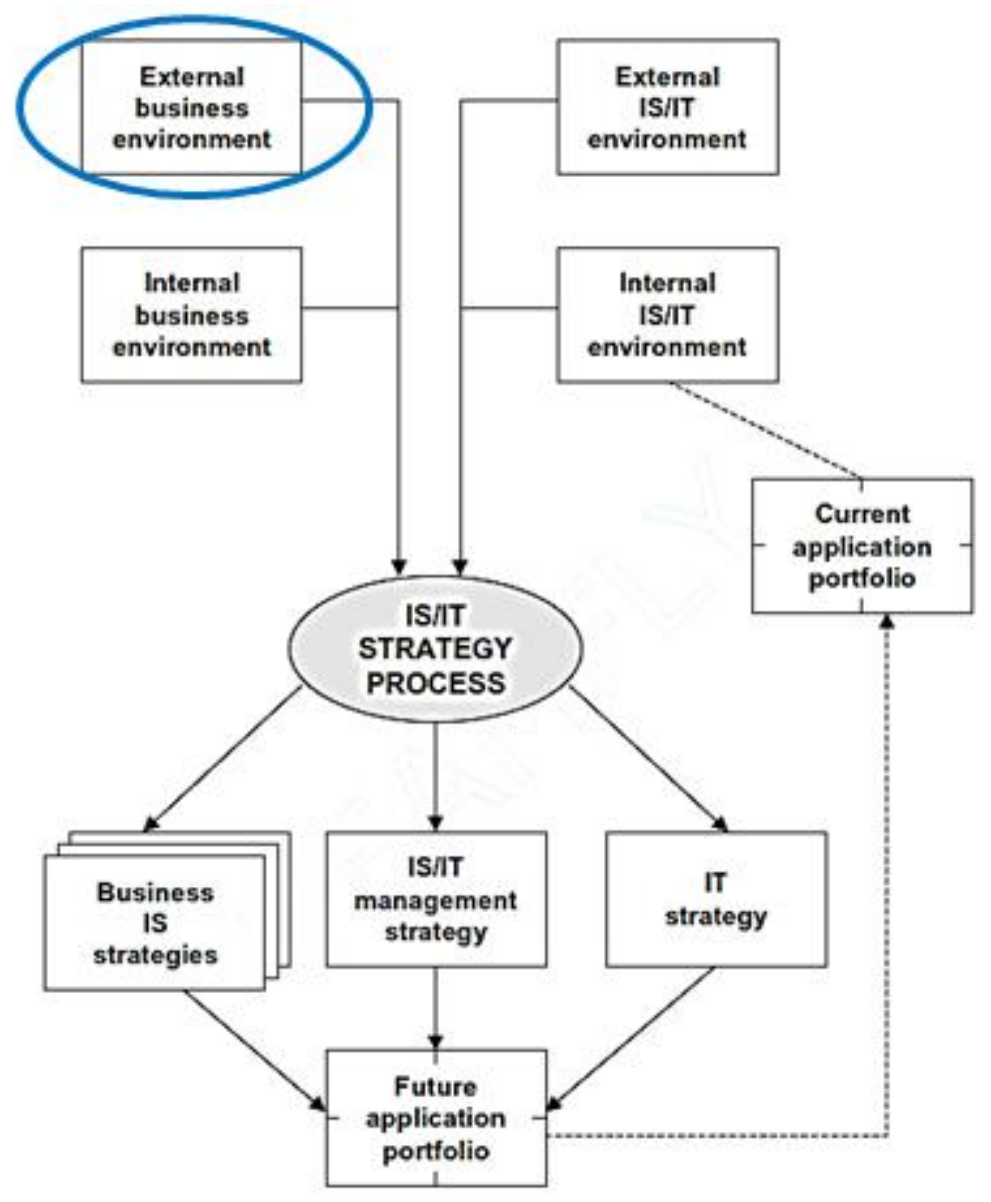

Gambar 1. Metodologi Ward dan Peppard [9] 
Lingkungan Eksternal Bisnis Dalam Perencanaan Strategis Sistem Informasi Pada Perusahaan

Kerupuk Di Kabupaten Indramayu

Dalam proses perencanaan strategis pada sistem informasi dan teknologi informasi tentunya banyak dipengaruhi dari berbagai faktor, akan tetapi di penelitian ini hanya meliputi lingkungan bisnis eksternal saja, seperti analisis PEST dan analisis Five Porters Force.

a. Analisis PEST

PEST analysis is the present complex world required as far as feasible, it considers the impact of important factors related to organization in strategic planning. In strategic planning, it can use different analitical methods and techniques that one of them [10].

b. Porter Five Force Analysis

Porter Five Force analysis as the forces are the threat of new, the threat of substitution,its mean of bargaining power of buyers, the bargaining power of supplier, and there fairly amongst existing competition in the industry [11].

\subsection{Perusahaan Kerupuk}

Undang-Undang No. 3 Tahun 1982, bahwa perusahaan adalah setiap bentuk usaha yang menjalankan setiap jenis usaha yang tetap dan terus menerus dan yang didirikan, bekerja serta berkedudukan dalam wilayah Negara Republik Indonesia untuk tujuan memperoleh keuntungan dan/atau laba.

a. Perusahan Kerupuk merupakan bentuk usaha yang mengolah dari barang-barang seperti tepung tapioka, udang dan ikan sebagai bahan belum jadi menjadi setengah jadi atau barang jadi dan produknya dipasarkan baik secara langsung ataupun melalui distributor.

\section{METODE PELAKSANAAN}

Berikut ini adalah diagram alur pada pengabdian pada masyarakat yang akan dilaksanakan pada PD Indrasari seperti yang dijelaskan pada gambar 2.

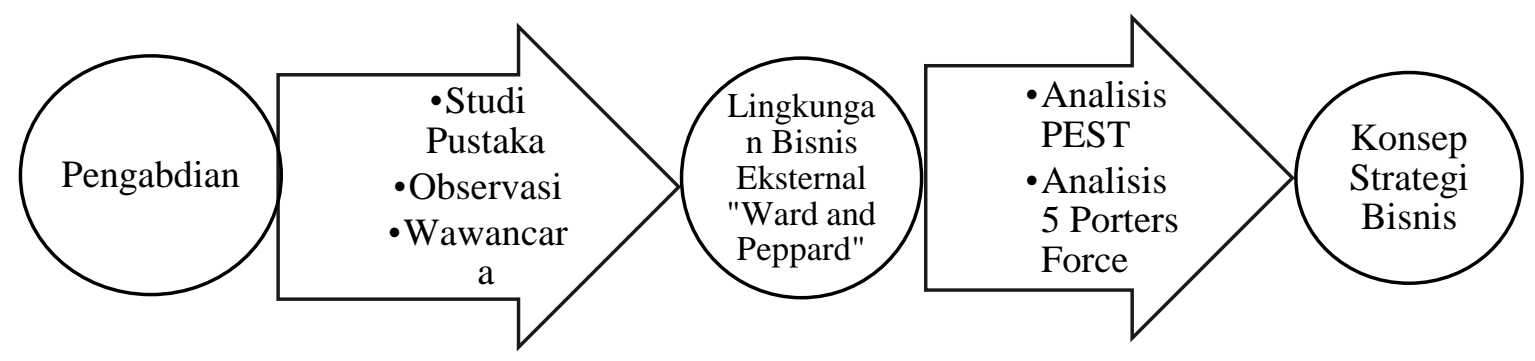

Gambar 2. Alur Pengabdian

1.3 Kegiatan Internal PD. Indrasari (Proses Bisnis).

a. Unit Pengolahan bahan baku, menyiapkan dan memproses bahan baku menjadi setengah jadi

b. Unit Pemotongan, memproses pemotongan barang setengah jadi.

c. Unit Penjemuran, proses yang bisa dikaitkan dengan keadaan iklim yang menunjang.

d. Unit penggorengan, unit ini bekerja bilamana barang yang akan dipasarkan bersifat barang siap saji (barang jadi).

e. Unit pengemasan (package), merupakan unit yang proses baik barang setengah jadi (tidak siap saji) ataupun barang jadi (siap saji) dan siap untuk dikemas dan di stok ke unit pemasaran.

f. Unit pemasaran, proses ini dibantu oleh beberapa UKM di perusahaan tersebut sehingga sampailah ke distributor (pasar) dan dapat dikatakan juga unit reject, bilamana ada penolakan karena barang cacat. 


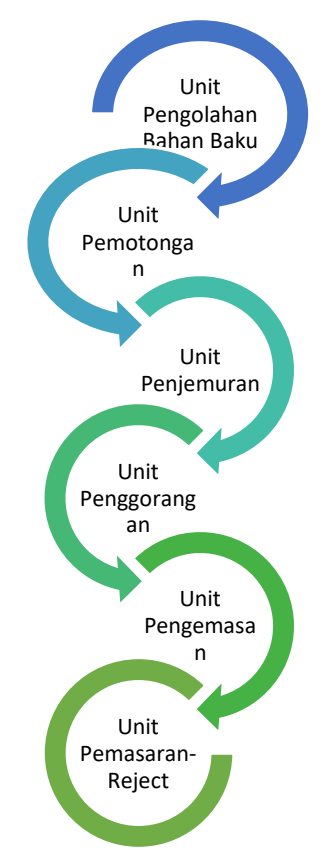

Gambar 3. Proses Bisnis PD Indrasari

1.4 Kegiatan Eksternal PD. Indrasari (Kerjasama dan Sosial), meliputi :

a. Membantu warga sekitar pabrik dalam kegiatan sosial

b. Mengikuti dan terdaftar sebagai anggota APKI (Asosiasi Pengusaha Kerupuk Indramayu)

c. Kerjasama dalam hal penanggulangan pencemaran limbah industri dengan departemen sosial atau terkait.

d. Bekerjasama dengan Pemerintah Daerah dan Pusat terutama dalam anggota IKM.

e. Mengikuti Seminar/ Workshop terkait dengan penggunaan jasa layanan secara elektronik (etax dan e-shop)

\section{HASIL DAN PEMBAHASAN PELAKSANAAN PENGABDIAN}

Dalam pelaksanaan pengabdian di PD. Indrasari, penulis melakukan beberapa analisis secara internal dan eksternal terutama dalam kegiatan di IKM tersebut, analisa dalam melaksanakan kegiatan internal di PD. Indrasari.

A. Perlu adanya rancangan/ desain bentuk kerupuk untuk menarik peminat menggunakan aplikasi coreldraw.

B. Perlu adanya rancangan pemasaran produk secara elektronik dengan menggunakan object oriented (UML).

C. Perlu adanya pembuatan ID kemasan bila terjadi kesalahan produk atau reject.

Analisa dalam melaksanakan kegiatan eksternal di PD. Indrasari adalah

A. Perlu adanya informasi baik jadwal tercetak maupun sistem informasi terkait dengan pelaksanaan kegiatan-kegiatan bersifat sosial ataupun peningkatan mutu IKM.

B. Perlu adanya informasi di media sosial tentang kegiatan-kegiatan IKM atau APKI.

Disisi lain penulis menggunakan metode John Ward and Joe Peppard terutama dalam mendeskripsikan pada lingkungan bisnis eksternalnya, sehingga bisa menjawab tantangan keunggulan kompetitif bisnis dan sebagai usulan khususnya untuk para pelaku usaha dan pemerintah daerah. Adapun hasil analisis bila dilihat dari masing - masing data, yaitu

1.5 Analisis PEST (Politik, Ekonomi, Sosial, Teknologi)

Konsep yang dihasilkan, yaitu: 
Lingkungan Eksternal Bisnis Dalam Perencanaan Strategis Sistem Informasi Pada Perusahaan

Kerupuk Di Kabupaten Indramayu

Tabel 1. Analisis PEST.

\begin{tabular}{|c|c|}
\hline DI & 11: \\
\hline $\begin{array}{l}\text { Dukungan dari Pemerintah Pusat } \\
\text { (Negara), Pemerintah Provinsi, dan } \\
\text { Pemerintah Daerah }\end{array}$ & $\begin{array}{l}\text { Memberikan insentif-insentif selain } \\
\text { dari upah karyawan dan buruh yang } \\
\text { tujuannya untuk kesejahteraan }\end{array}$ \\
\hline $\begin{array}{l}\text { Hal yang penting yaitu dukungan yang } \\
\text { terkait dengan bahan pokok produksi, } \\
\text { permodalan melalui investasi dari } \\
\text { pihak swasta }\end{array}$ & $\begin{aligned} & \text { karyawan dan buruh. } \\
> & \text { Memberikan harga jual yang } \\
& \text { terjangkau oleh konsumen } \\
> & \text { Menjadikan PD. Indrasari percontohan }\end{aligned}$ \\
\hline $\begin{array}{l}\text { Kerjasama yang selalu } \\
\text { pihak pemerintah dae }\end{array}$ & $\begin{array}{l}\text { perdagangan yang modern yang } \\
\text { bersifat tradisional dan teknologi }\end{array}$ \\
\hline $\begin{array}{l}\text { diterbitkan kebijakan- } \\
\text { lebih mengarah du }\end{array}$ & $\begin{array}{l}\text { Perlunya kerjasama dengan para } \\
\text { penyedia bahan baku }\end{array}$ \\
\hline pelaku bisnis dan usaha & $>$ Mengadakan \\
\hline $\begin{array}{l}\text { Membuat suatu kebijakan terkait } \\
\text { kesejahteraan karyawan dan buruh } \\
\text { serta warga di lingkungan pabrik }\end{array}$ & $\begin{array}{l}\text { in udang } \\
\text { nbuat kemasan } \\
\text { nomis }\end{array}$ \\
\hline SOSIAL & TEKN \\
\hline $\begin{array}{l}>\text { Perlu dibuatkan selokan/ irigasi } \\
\text { pembuangan limbah cair } \\
>\text { Perlunya sosialisasi lingkungan hidup }\end{array}$ & $\begin{array}{l}\text { Perlu dikembangkanya website PD. } \\
\text { Indrasari yang berkonten profil dan } \\
\text { profit perusahaan }\end{array}$ \\
\hline $\begin{array}{l}\text { untuk warga sekitar pabrik } \\
\text { Bakti sosial yang lebih mendekatkan } \\
\text { antara perusahaan dengan warga yang }\end{array}$ & $\begin{array}{l}\text { Perlu dirancangnya aplikasi yang } \\
\text { mendukung terkait pemasaran, } \\
\text { layanan konsumen }\end{array}$ \\
\hline bukan sekeda & $\begin{array}{c}\text { Dibuatkan rancangan aplikasi yang } \\
\text { berkaitan dengan penyaluran, }\end{array}$ \\
\hline & kerjasama, aplikasi C2C, B2C \\
\hline
\end{tabular}

\subsection{Analisis Porter Five Forces}

Berikut ini adalah siklus analisis Porter Five Forces seperti pada gambar 4.

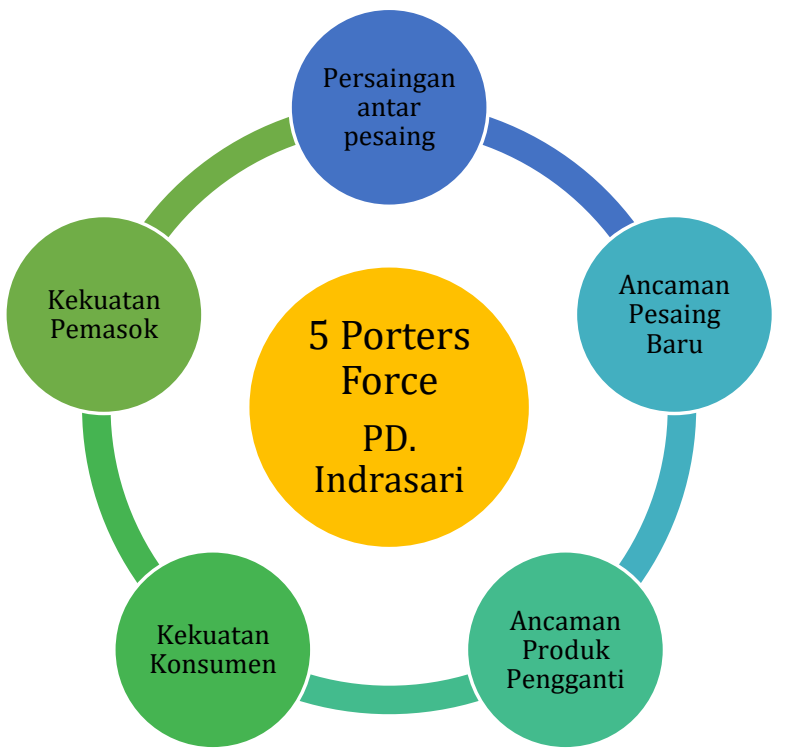

Gambar 4. Analisis Porter Five Forces 
Konsep diperoleh adalah sebagai berikut:

a. Persaingan antar pesaing (Rivalry among existing competitors)

Persaingan dengan IKM sejenis dalam tingkat daerah masih terbilang kecil, akan tetapi untuk tingkat nasional terbilang menengah pesaing, karena bisnis kerupuk udang atau ikan merupakan bisnis industri kecil. Adanya pernyataan tersebut sebaiknya IKM tersebut untuk meningkatkan promosi produk.

b. Ancaman Pesaing Baru (Threat of New Entrants)

Kelompok pengolah yang baru (pesaing) terkadang tidak dapat melanjutkan dikarenakan stok bahan baku yang sulit karena menggunakan ikan jenis tertentu, sehingga pabrik ataupun kelompok pengolah tersebut akan mengalami gulung tikar dalam jangka waktu 6 bulan s.d. 12 bulan. Disimpulkan bahwa perlunya manajemen pengelolaan terpadu pada IKM tersebut, sehingga apabila ada permasalahan di tiap bagian/unit akan segera ditangani.

c. Ancaman Produk Pengganti (Treatment of substitute product or service)

Munculnya pabrik/ organisasi yang terlibat dalam perdagangan keripik kulit ikan merupakan produk pengganti dari kerupuk, akan tetapi produk tersebut mengalami kesulitan dalam bahan bakunya (kulit ikan). Sehingga kemungkinan kecil adanya produk pengganti. Sebaiknya IKM lebih diarahkan ke kreativitas dan inovasi bentuk produk, sehingga ancaman bentuk dan rasa bias menjadi sasaran.

d. Kekuatan Konsumen/ Pengguna (Bargaining Power of Buyers)

Seiring dengan berkembangnya pedagang keripik kulit ikan yang dikonsumsi sehari - hari sebagai teman hidangan makanan dan bertambahnya pabrik keripik kulit ikan, maka efek konsumen/ pembeli berkurang untuk kerupuk udang dan ikan, akan tetapi tidak begitu signifikan. Bahwa ini bisa ditangani dengan menerapkan strategi promosi, harga, dan antar barang kepada konsumen tunggal atau toko.

e. Kekuatan Pemasok/ Investasi (Bargaining Power of Suppliers)

Dengan banyaknya pemasok (nelayan tambak/nelayan laut) yang memiliki nilai tawar yang kuat bagi perusahaan/IKM. Jika pemasok tersebut memberikan/memasok ke perusahaan selain IKM dengan harga yang relatif murah, dapat memberikan kesulitan bagi IKM untuk menentukan harga yang bersaing. Pernyataan di atas dapat disimpulkan bahwa perlu adanya bantuan dari pihak pemerintah terutama terkait harga kebutuhan bahan baku.

\section{SIMPULAN}

Untuk menyusun konsep strategi bisnis pada PD. Indrasari Desa Kenanga Kabupaten Indramayu, dengan menggunakan pendekatan John Ward and Joe Peppard yaitu dengan menganalisis lingkungan bisnis eksternal pada lingkungan Politik, Ekonomi, Sosial, dan Teknologi serta menganalisis 5 Porter Forces, yaitu persaingan antar pesaing, ancaman pesaing baru, ancaman produk pengganti, kekuatan konsumen, dan kekuatan pemasok. Adapun tahapan-tahapan untuk memperoleh analisis lingkungan bisnis eksternalnya, 1) Tahap Pertama: menentukan dan mengolah data analisis PEST, yaitu dengan memperoleh deskripsi berupa dukungan dan pengawasan pemerintah pusat, pemerintah provinsi, dan pemerintah daerah serta adanya kebijakan-kebijakan yang mendorong produktivitas perusahaan. 2) Tahap Kedua : menentukan dan mengolah data analisis Five Porter Forces, seperti persaingan antar pesaing masih terbilang kecil karena jumlah perusahaan kerupuk di Kabupaten Indramayu masih sedikit, di tahun 2018 kurang dari 40 IKM; untuk ancaman pesaing baru masih kurang karena IKM ini masih bersifat konvensional baik produksi maupun teknologi informasi; dilihat dari ancaman produk pengganti bahwa dari pemaparan para responden masih kemungkinan kecil, karena bahan baku yang kurang; kekuatan konsumen dibuktikan bahwa karakteristik rasa yang beda dengan keripik kulit ikan, sehingga konsumen enggan berpindah; Kabupaten Indramayu merupakan daerah strategis pemasok 
Lingkungan Eksternal Bisnis Dalam Perencanaan Strategis Sistem Informasi Pada Perusahaan

Kerupuk Di Kabupaten Indramayu

udang dan ikan dan disebut sebagai ketahanan pangan, itu merupakan kekuatan pemasok walau tergantung dengan keadaan alam. Dari beberapa hasil analisis di atas, maka disimpulkan konsep strategi bisnis pada PD. Indrasari perlu dukungan politik, dukungan ekonomi, dukungan sosial, dukungan teknologi, dukungan sarana-prasarana, dukungan konsumen, dukungan distributor, dukungan supplier, dan dukungan sumberdaya manusia yang unggul.

\section{UCAPAN TERIMA KASIH}

Dalam penyampaian ucapan terima kasih ini disampaikan pada seluruh pihak yang telah berkostribusi dalam penulisan artikel ini.

- Direktur AMIK Purnama Niaga, Indramayu.

- Pembantu Direktur II AMIK Purnama Niaga, Indramayu.

- Ketua LPPM AMIK Purnama Niaga, Indramayu.

- Ketua APKI Kabupaten Indramayu

\section{DAFTAR PUSTAKA}

[1] M. D. P. Saad and H. Siagian, "Sentimen Investor, Kendala Keuangan, dan Equity Market Timing," Financ. Bank., vol. 13, no. 1, pp. 1-15, 2011.

[2] S. Zuhri, "Analisis Pengembangan Usaha Kecil home Industri Sangkar Ayam Dalam Rangka Pengentasan Kemiskinan," Manaj. dan Akunt., vol. 2, no. 3, pp. 46-65, 2013.

[3] H. Nurdiyanto and H. Meilia, "SPK Penentuan Prioritas Pengembangan Industri Kecil Menggunakan metode Analitical Hierarchy Proces (AHP)," pp. 6-7, 2016.

[4] Https://kemenperin.go.id/artikel/18855, “Jumlah-Unit-Usaha-dan-Tenaga-Kerja-IKMDitargetkan-Naik-Setiap-Tahun/diakses tanggal 14 Mei 2020.”

[5] D. Pelawi, C. Willy, and B. Irwanza, "Perencanaan Strategi Sistem Dan Teknologi Informasi Pada PT. Tripuri Mitra Nobelindo," pp. 341-355.

[6] R. E. Indrajit, Manajemen Sistem Informasi dan Teknologi Informasi. Jakarta: Elex Media Komputindo, 2000.

[7] Ari Wedhasmara, "Langkah-Langkah Perencanaan Strategis Sistem Informasi Dengan Metode Ward And Peppard,” J. Sist. Inf., vol. 1, no. 1, pp. 14-22, 2009.

[8] J. and J. P. Ward, "Strategic Planning for Information System 3nd," in Third Edition, England: John Wiley \& Sons, 2002, p. 44.

[9] A. Setiawan and E. Yulianto, "Information System Strategic Planning Using IT Balanced Scorecard In Ward \& Peppard Framework Model,” Int. J. Eng. Technol., vol. 9, no. 3, pp. 1864-1872, 2017.

[10] A. Gupta, A. Officer, and W. Kalan, "Environment \& PEST Analysis : An Approach to External Business Environment," vol. 2, no. 1, pp. 34-43, 2013.

[11] M. Mittal, "Competitive Analysis of Nissan Motors Pvt Ltd . Beyond Porter's 5 Force Model,”vol. 6, no. 3, 2017. 